\title{
Publisher Correction: A stabilized glycomimetic conjugate vaccine inducing protective antibodies against Neisseria meningitidis serogroup A
}

\author{
Jacopo Enotarpi, Marta Tontini, Cristiana Balocchi, Daan van der Es (D), Ludovic Auberger (D), Evita Balducci, \\ Filippo Carboni, Daniela Proietti, Daniele Casini, Dmitri V. Filippov, Hermen S. Overkleeft, Gijsbert A. van \\ der Marel, Cinzia Colombo, Maria Rosaria Romano, Francesco Berti (D), Paolo Costantino, Jeroen D. C. Codeé (D), \\ Luigi Lay (1) \& Roberto Adamo (D)
}

Correction to: Nature Communications https://doi.org/10.1038/s41467-020-18279-x, published online 7 September 2020.

The original version of this Article contained errors in Fig. 1. The label 'a' was omitted for the left panel and the label 'b' was omitted for the right panel. In Fig. 1b, the right parenthesis was incorrectly positioned indicating a 4-carbon linker, rather than the correct 6-carbon linker. These errors have been corrected in both the PDF and HTML versions of the Article.

Published online: 25 November 2020

\footnotetext{
(c) (i) Open Access This article is licensed under a Creative Commons Attribution 4.0 International License, which permits use, sharing, adaptation, distribution and reproduction in any medium or format, as long as you give appropriate credit to the original author(s) and the source, provide a link to the Creative Commons license, and indicate if changes were made. The images or other third party material in this article are included in the article's Creative Commons license, unless indicated otherwise in a credit line to the material. If material is not included in the article's Creative Commons license and your intended use is not permitted by statutory regulation or exceeds the permitted use, you will need to obtain permission directly from the copyright holder. To view a copy of this license, visit http://creativecommons.org/licenses/by/4.0/.
}

(C) The Author(s) 2020 